\title{
Response Times of Motorcycle Ambulances during the COVID-19 Pandemic
}

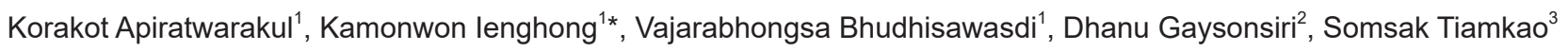 \\ ${ }^{1}$ Department of Emergency Medicine, Faculty of Medicine, Khon Kaen University, Khon Kaen, Thailand; ${ }^{2}$ Department of \\ Pharmacology, Faculty of Medicine, Khon Kaen University, Khon Kaen, Thailand; ${ }^{3}$ Department of Medicine, Faculty of Medicine, \\ Khon Kaen University, Khon Kaen, Thailand
}

Edited by: Sasho Stoleski Citation: Apiratwarakul K, lenghong K, Bhudhisawasdi V, Gaysonsiri D, Tiamkao S. Response Times of Motorcycle Ambulances during the COVID-19 Pandemic. Open Access Maced J Med Sci. 2020 Dec 01; 8(T1):526-529. https://doi.org/10.3889/oamjms.2020.5527
Keywords: COVID-19; Viruses; Ambulances; Emergency medical services; Response time

*Correspondence: Kamonwon lenghong, Departmen of Emergency Medicine, Khon Kaen University, Khon Kaen - 40002, Thailand. E-mail: kamonwan@kku.ac.th Received: 28-Sep-2020 Revised: 10-Nov-2020 Accepted: 21-Nov-2020 Copyright: ๑ 2020 Korakot Apiratwarakul, Kamonwon lenghong, Vajarabhongsa Bhudhisawasdi, Dhanu Gaysonsiri, Somsak Tiamkao
Funding: Publication of this article was fincilly Funding: Publication of this article was financially Republic of Macedonia Competing Interests: The authors have declared that no Open Access: This is an open-access article distribute under the terms of the Creative Commons Attribution-
NonCommercial 4.0 International License (CC BY-NC 4.0)

\section{Abstract}

BACKGROUND: Motorcycles (motorlance) are often deployed as ambulances to the scene of an emergency to reduce response time. The COVID-19 pandemic has affected emergency medical services (EMS) in Thailand in many respects, and this study was conducted to examine its effect on motorlance operation time.

AIM: The aim of the study was to examine motorlance operation time during the COVID-19 pandemic in comparison to normal periods.

METHODS: This cross-sectional study examined all EMS motorlance operations dispatched from Srinagarind Hospital (Thailand). Data were collected from the Srinagarind Hospital EMS operation database and hospital information database system. Data from June 1, 2018, to December 31, 2019 (normal period) were compared with those from January 13 to April 21, 2020 (COVID-19).

RESULTS: Eight hundred seventy-one EMS operations were examined over two periods. Mean patient age during the COVID-19 pandemic was $41.5 \pm 6.2$ years, and $54.6 \%(n=59)$ were male. Average response time was $6.20 \pm$ 1.35 min during the normal period and $3.48 \pm 1.01 \mathrm{~min}$ during the pandemic $(p=0.021)$. Transport time was also significantly shorter during the latter period ( $2.35 \mathrm{vs}$. $5.20 \mathrm{~min})$.

CONCLUSIONS: Motorlance response and transport time during the COVID-19 pandemic were significantly shorter than usual.

\section{Introduction}

Motorcycles (motorlance) are often deployed as ambulances to the scenes of emergencies in large cities with traffic problems or during rush hour to reduce response time [1]. They allow for rapid access to patients, reduced waiting times, and increased response to emergency expectations [2]. The motorlance can also be used to deliver patients with mild symptoms or pregnant women from primary care units to the hospital [3], [4]. In Scandinavian countries, motorlances are used in cases of cardiac arrest outside the hospital or severe accidents to allow for rapid access to the scene [5], [6]. In addition, a previous study found that the costs of using a motorlance were lower than those of van ambulances [7]. Motorlances can be used in both basic and advanced emergency situations, including those requiring a defibrillator [8]. In South Korea, there is a 5-min time limit to reach patients with out-of-hospital cardiac arrest (OHCA). In the United States, the time allowed to reach a trauma patient is no more than 9 min [9]. Because of this, various efforts have been made to reduce the time it takes to reach patients [10], [11], [12], [13].
The COVID-19 (novel coronavirus 2019, 2019-nCoV) pandemic, announced by the world health organization in mid-March 2020 and continuing into the present [14], [15], [16], [17], [18] has affected health services [19], [20], socioeconomics, and people's lifestyles, all of which are factors that impact emergency medical services (EMS). However, there have yet been no studies of motorlance response time during the COVID-19 pandemic. This study was thus conducted to compare EMS operation time through motorlance during the pandemic versus normal periods.

\section{Methods}

The present study protocol was approved by the Khon Kaen University Ethics Committee for Human Research (HE631278). The requirement for informed consent from the patients was waived since patient confidentiality protection had been guaranteed by identifying them using a unique study number, rather than by name. 


\section{Study population and design}

This cross-sectional study examined all motorlance operations dispatched from Srinagarind Hospital through Thailand's emergency telephone services (number: 1669). Cases in which the patients were under 18 years of age or for which there were missing data were excluded from this study. Data were recorded using the operation national standard checklist for EMS in Thailand. Data were collected from the Srinagarind Hospital EMS operation database and hospital information database system.

\section{Definitions}

Motorlance service during the COVID-19 pandemic was defined as operations in which a motorlance was deployed between January 13 and April 21, 2020 (the date of the first confirmed case of COVID-19 in Thailand according to the Ministry of Public Health and day 100). We used the period from June 1, 2018, to December 31, 2019, as a normal period for comparison. Activation time was defined as the time from dispatch to resources being en route, response time was defined as time from 1669 center call receipt to arrival on scene, on-scene time was defined as the time between the responding ambulance arriving on location and its departure with the patient to the emergency department, and transport time was defined as the time from the scene of the emergency to arrival at the hospital. Time from dispatch to the arrival of the automated external defibrillator (AED) on scene was defined as AED waiting time.

\section{Statistical analysis}

The sample size was calculated based on the number of motorlance deployments from Srinagarind Hospital EMS by Apiratwarakul [13]. To achieve a significance level of $5 \%$ and power of test of 0.8 , we determined that a sample size of 871 would be required. Statistical analysis was performed using SPSS for Windows version 16.0 (SPSS Inc., Chicago, IL, USA). Categorical data were presented as percentages, and continuous data were presented using mean and standard deviation. Univariable analysis was performed using a two-sample t-test for numerical data and a Pearson's correlation for data relationships between the two groups.

\section{Results}

Eight hundred seventy-one EMS operations were examined over the two periods of the study, $108(12.4 \%)$ of which were conducted during the COVID-19 pandemic. The characteristics of the subjects and services are shown in Table 1. The mean age of patients who received motorlance service during the pandemic was $41.5 \pm 6.2$ years, and $54.6 \%(n=59)$ were male. Operations in both groups were most commonly performed on nonholidays $(68.3 \%$ during the normal period and $59.3 \%$ during COVID-19). Most cases in both groups involved non-trauma patients. The severity of patients' signs and symptoms were classified by color according to the Thai criteria-based dispatch (CBD) triage system. During the COVID-19 pandemic, CBD codes were red in $11.1 \%$ of cases, yellow in $48.1 \%$, and green in $40.8 \%$.

Table 1: Characteristics of the subjects

\begin{tabular}{llll}
\hline Characteristics & $\begin{array}{l}\text { Normal period } \\
(\mathrm{n}=763), \mathrm{n}(\%)\end{array}$ & $\begin{array}{l}\text { COVID-19 pandemic } \\
\text { service }(\mathrm{n}=108), \mathrm{n}(\%)\end{array}$ & $\mathrm{p}$-value \\
\hline Age (years) Mean \pm SD & $38.4 \pm 5.2$ & $41.5 \pm 6.2$ & 0.202 \\
$\begin{array}{l}\text { Sex: male } \\
\text { Operation day }\end{array}$ & $398(52.2)$ & $59(54.6)$ & 0.852 \\
$\quad$ Non-holiday & & & \\
$\quad$ Holiday & $521(68.3)$ & $64(59.3)$ & 0.651 \\
Type & $242(31.7)$ & $44(41.7)$ & 0.752 \\
$\quad$ Non-trauma & & & \\
$\quad$ Trauma & $548(71.8)$ & $82(75.9)$ & 0.810 \\
EMS triage level & $215(28.2)$ & $26(24.1)$ & 0.740 \\
$\quad$ Red & $103(13.5)$ & $12(11.1)$ & 0.650 \\
$\quad$ Yellow & $375(49.1)$ & $52(48.1)$ & 0.742 \\
$\quad$ Green & $285(37.4)$ & $44(40.8)$ & 0.785 \\
\hline
\end{tabular}

Activation times during the normal period and the COVID-19 pandemic were $0.58 \pm 0.20$ and $0.56 \pm 0.12 \mathrm{~min}$, respectively $(p=0.680$; Table 2$)$, and response times were $6.20 \pm 1.35$ and $3.48 \pm 1.01 \mathrm{~min}$, respectively $(p=0.021)$. Transport time during the pandemic was significantly lower than in the other period (2.35 vs. $5.20 \mathrm{~min}$ ).

Table 2: Operation time in motorlance

\begin{tabular}{llll}
\hline $\begin{array}{l}\text { Operation time }(\mathrm{min}) \\
\text { Mean } \pm \text { SD }\end{array}$ & $\begin{array}{l}\text { Normal services } \\
(\mathrm{n}=763)\end{array}$ & $\begin{array}{l}\text { COVID-19 pandemic } \\
\text { service }(\mathrm{n}=108)\end{array}$ & $\mathrm{p}$-value \\
\hline Activation time & $0.58 \pm 0.20$ & $0.56 \pm 0.12$ & 0.680 \\
Response time & $6.20 \pm 1.35$ & $3.48 \pm 1.01$ & $0.021^{*}$ \\
On-scene time & $6.41 \pm 1.20$ & $6.33 \pm 1.17$ & 0.577 \\
Transport time & $5.20 \pm 0.58$ & $2.35 \pm 1.01$ & $0.010^{*}$ \\
\hline "Statistical significance. & & &
\end{tabular}

Motorlances were dispatched to cardiac arrest patients a total of 38 times. Response times during the normal period and the COVID-19 pandemic were 7.11 $\pm 0.42 \mathrm{~min}$ and $4.01 \pm 0.20 \mathrm{~min}$, respectively $(p<0.001$; Table 3). Mean AED waiting time during the pandemic was also significantly lower than in the normal period (3.20 vs. $5.20 \mathrm{~min}$ ), but the mortality rates of the two groups were similar.

Table 3: Motorlance services for cardiac arrest patients

\begin{tabular}{llll}
\hline Procedures & $\begin{array}{l}\text { Normal services } \\
(\mathrm{n}=33)\end{array}$ & $\begin{array}{l}\text { COVID-19 pandemic } \\
\text { service }(\mathrm{n}=5)\end{array}$ & $\mathrm{p}$-value \\
\hline Response time $(\min )$ Mean \pm SD & $7.11 \pm 0.42$ & $4.01 \pm 0.20$ & $<0.001^{*}$ \\
AED waiting time (min) Mean \pm SD & $5.20 \pm 0.26$ & $3.20 \pm 0.36$ & $<0.001^{*}$ \\
Mortality, $\mathrm{n}(\%)$ & & & \\
$\quad$ Survived & $4(12.1)$ & $1(20.0)$ & 0.068 \\
$\quad$ Did not survive & $28(87.9)$ & $4(80.0)$ & 0.055 \\
\hline${ }^{*}$ Statistical significance. & & &
\end{tabular}

\section{Discussion}

This study is a comparison of EMS motorlance operation during the COVID-19 pandemic versus normal 
circumstances. Motorlance response and transport time during the pandemic were significantly lower than during the normal period [13], [21], [22], [23]. This is likely due to reduced traffic as a result of workplaces and schools being closed and more people staying home in general. The most important function of a motorlance is to reach the scene quickly, assess symptoms, and provide the necessary treatment. Less important is its role in delivering patients to the hospital, which is usually carried out using a traditional ambulance. However, in many African countries, the Motorlances play a greater role in patient transport, mostly because of shortages of other types of ambulance. Previous studies have found correlations between national economic indicators and EMS response time [15], [16], [17], [18].

We also found decreases in response and AED waiting times (when the AED is attached to a motorlance) for patients with OHCA during the COVID-19 pandemic. In addition, response time was lower than in previous studies, which has varied from 5 to 15 min depending on the country, but in most countries, it was $8 \mathrm{~min}$. These findings demonstrate the efficiency of the EMS unit in terms of notification of the incident, response of EMS members, and management of the vehicle en route. It may also be due to the fact that the area for which Srinagarind Hospital EMS is responsible is relatively small, including only a university and the surrounding communities. In addition, the small roads in the area are more suitable for motorcycles than larger vehicles. Although response and AED waiting times for OHCA patients were lower during the pandemic, there was no significant difference in mortality rate between the two periods.

The present study was limited in that data were gathered from only one EMS center and that the study design was retrospective, which may have resulted in incomplete data collection [24], [25].

\section{Conclusions}

The motorlance response and transport times during the COVID-19 pandemic were significantly lower than normal, both overall and in cases of OHCA.

\section{Acknowledgments}

The authors would like to thank Jiranan Thedmee, Thanyaporn Simsen, and Siwaporn Kwansanei for their data analysis and statistical review and Dylan Southard for acting as English consultant.

\section{References}

1. Soares-Oliveira M, Egipto P, Costa I, Cunha-Ribeiro LM. Emergency motorcycle: Has it a place in a medical emergency system? Am J Emerg Med 2007;25(6):620-2. https://doi. org/10.1016/j.ajem.2006.11.030

\section{PMid: 17606085}

2. van der Pols H, Mencl F, de Vos R. The impact of an emergency motorcycle response vehicle on prehospital care in an urban area. Eur J Emerg Med 2011;18(6):328-33. https://doi. org/10.1097/mej.0b013e32834624e8

PMid:22048417

3. Ssebunya R, Matovu JK. Factors associated with utilization of motorcycle ambulances by pregnant women in rural eastern Uganda: A cross-sectional study. BMC Pregnancy Childbirth 2016;16:46. https://doi.org/10.1186/s12884-016-0808-0

4. Wilson A, Hillman S, Rosato M, Skelton J, Costello A, Hussein J, et al. A systematic review and thematic synthesis of qualitative studies on maternal emergency transport in low and middleincome countries. Int J Gynaecol Obstet 2013;122(3):192-201. https://doi.org/10.1016/j.ijgo.2013.03.030

PMid:23806250

5. Nakstad AR, Bjelland B, Sandberg M. Medical emergency motorcycle-is it useful in a Scandinavian emergency medical service? Scand J Trauma Resusc Emerg Med 2009;17:9. https://doi.org/10.1186/1757-7241-17-9

PMid:19239681

6. Harmsen AM, Giannakopoulos GF, Moerbeek PR, Jansma EP Bonjer HJ, Bloemers FW. The influence of prehospital time on trauma patients outcome: A systematic review. Injury 2015;46(4):602-9. https://doi.org/10.1016/j.injury.2015.01.008 PMid:25627482

7. Hofman JJ, Dzimadzi C, Lungu K, Ratsma EY, Hussein J. Motorcycle ambulances for referral of obstetric emergencies in rural Malawi: Do they reduce delay and what do they cost? Int J Gynaecol Obstet 2008;102(2):191-7. https://doi.org/10.1016/j. ijgo.2008.04.001

PMid:18555998

8. Lin CS, Chang H, Shyu KG, Liu CY, Lin CC, Hung CR, et al. A method to reduce response times in prehospital care: the motorcycle experience. Am J Emerg Med 1998;16(7):711-3. https://doi.org/10.1016/s0735-6757(98)90185-1

PMid:9827757

9. Byrne JP, Mann NC, Dai M, Mason SA, Karanicolas P, Rizoli S, et al. Association between emergency medical service response time and motor vehicle crash mortality in the United States. JAMA Surg 2019;154(4):286-93. https://doi.org/10.1001/ jamasurg.2018.5097 PMid:30725080

10. Kim TH, Lee EJ, Shin SD, Ro YS, Kim YJ, Ahn KO, et al. Neurological favorable outcomes associated with EMS compliance and on-scene resuscitation time protocol. Prehosp Emerg Care 2018;22(2):214-21. https://doi.org/10.1080/109031 27.2017.1367443

PMid:28952823

11. Cantwell K, Morgans A, Smith K, Livingston M, Spelman T, Dietze P. Time of day and day of week trends in EMS demand. Prehosp Emerg Care 2015;19(3):425-31. https://doi.org/10.310 9/10903127.2014.995843 PMid:25664379

12. Cabral EL, Castro WR, Florentino DR, Viana DA, Costa JF Jr., Souza RP, et al. Response time in the emergency services. Systematic review. Acta Cir Bras 2018;33(12):1110-21. https:// doi.org/10.1590/s0102-865020180120000009 
PMid:30624517

13. Apiratwarakul $K$, lenghong $K$, Mitsungnern $T$, Kotruchin $P$, Phungoen P, Bhudhisawasdi V. Use of a motorlance to deliver emergency medical services: A prospective cross sectional study. Arch Acad Emerg Med 2019;7:e48.

PMid:31602431

14. He F, Deng Y, Li W. Coronavirus disease 2019: What we know? J Med Virol 2020;92(7):719-25.

PMid:32170865

15. Lake MA. What we know so far: COVID-19 current clinical knowledge and research. Clin Med (Lond) 2020;20(2):124-7. https://doi.org/10.7861/clinmed.2019-coron PMid:32139372

16. Guo YR, Cao QD, Hong ZS, Tan YY, Chen SD, Jin HJ, et al. The origin, transmission and clinical therapies on coronavirus disease 2019 (COVID-19) outbreak an update on the status. Mil Med Res 2020;7(1):11. https://doi.org/10.1186/s40779-020-00240-0

17. Grasselli G, Pesenti A, Cecconi M. Critical care utilization for the COVID-19 outbreak in Lombardy, Italy: Early experience and forecast during an emergency response. JAMA 2020;323(16):1545-6. https://doi.org/10.1001/jama.2020.4031 PMid:32167538.

18. Lauer SA, Grantz KH, Bi Q, Jones FK, Zheng Q, Meredith HR, et al. The incubation period of coronavirus disease 2019 (COVID-19) from publicly reported confirmed cases: Estimation and application. Ann Intern Med 2020;172:577-82. https://doi. org/10.7326/m20-0504

PMid:32150748

19. Nishiura $H$, Linton NM, Akhmetzhanov AR. Serial interval of novel coronavirus (COVID-19) infections. Int J Infect Dis 2020;93:284-6. https://doi.org/10.1101/2020.02.03.20019497 PMid:32145466

20. Baig AM, Khaleeq A, Ali U, Syeda H. Evidence of the COVID19 virus targeting the CNS: Tissue distribution, host-virus interaction, and proposed neurotropic mechanisms. ACS Chem Neurosci 2020;11(7):995-8. https://doi.org/10.1021/ acschemneuro.0c00122

21. Apiratwarakul $K$, Srimookda N, Phungoen $P$, lenghong $K$, Tiamkao S, Bhudhisawasdi V. Presepsin levels in emergency patients with bacterial and viral infection. Open Access Maced J Med Sci 2020;8:20-3. https://doi.org/10.3889/ oamjms.2020.3204

22. Apiratwarakul $\mathrm{K}$, Jumroenketpratheep $\mathrm{K}$, lenghong $\mathrm{K}$, Ruttanaseeha W, Buranasakda M, Bhudhisawasdi V. Hand hygiene of emergency medical service healthcare providers. $J$ Med Assoc Thai 2020;103:8-10.

23. lenghong K, Kulsutcharit K, Apiratwarakul K, Gaysonsiri D, Mitsungnern T, Bhudhisawasdi V. Characteristics and mortality in high, intermediate, and low-risk acute pulmonary embolism patients in the emergency department. J Med Assoc Thai 2020;103:42-6.

24. Apiratwarakul $\mathrm{K}$, Mitsungnern $\mathrm{T}$, Thatphet $\mathrm{P}$, lenghong $\mathrm{K}$, Ruttanaseeha W, Bhudhisawasdi V. Management of anaphylactic patients by emergency medical services. J Med Assoc Thai 2020;103:11-4.

25. Apiratwarakul K, lenghong K, Gaysonsiri D, Buranasakda M, Bhudhisawasdi V, Tiamkao S. Role of motorcycle-based ambulance (motorlance) in major sporting events. J Med Assoc Thai 2020;103:15-7. 